\title{
回収ボイラの現状技術と将来の展望
}

\author{
川崎キ重プラン業業部 松 田 孝 男

\section{Present Technique and Future View for Recovery Boiler}

\author{
Takao Matsuda
}

KAWASAKI HEAVY INDUSTRIES, LTD. ENERGY PLANT ENGINEERING DIVISION

\begin{abstract}
This paper describes the history, present technique and the future view for the recovery boiler which is one of the most important equipment in the kraft pulp recovery system. The recovery boilers installed in the last three years have been completed with improved efficiency system — high steam condition, low pollution, high smelt reduction rate and computer control etc.
\end{abstract}

\section{1.はじめに}

クラフトパルプ回収クローズドサイクル中に位着す る回収ボイラは, 使用燃料 (黒液) が腐食性を有する ことや排ガス中に多量のダストを含むなどのため，そ

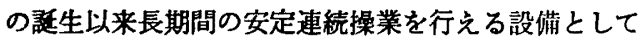
いくことに力の大半が費やされてきたといっても過言 ではない。しかし近年においてはェネルギー有効利用 の見地から，また省蒸気の進展により回収ボイラが工 場内エネルギーの大半をまかなら傾向にあり，このた め安定連続操業に加え, 回収ボイラの高効率操業は工 場全体の生産性を左右する重要なポイントとなってい る。更にェネルギー資源のほとんどすへてを海外に依 存している我が国においては自給エネルギーの有効活 用は今後益々要求される点であり, 従って回収ボイラ への期待度は更に高まるものと考えられる。

このよらに KP工場の中柇設備となっている回収ボ イラの変㖶をふり返ると共に現状の技術を紹介し，更 に今後の課題ならびに将来の展望について記述する。

\section{2. 国内における回収ボイラの変要}

スプレー式回収ポイラに限定してその変要をたどる。

\section{1 設贯午数およひ黑液固形分処理是}

昭和 27 年に設置されて以降, 昭和 62 年初頭完成予
定までの 2 年毎の設置缶数とその累計を図 1 に示す。 （現在休・廃缶をも含む一以下同様）また設置缶の 黑液固形分処理量の和とその累計を図 2 に示す。

これら両図から回収ボイラの，ひいてはパルプ産業

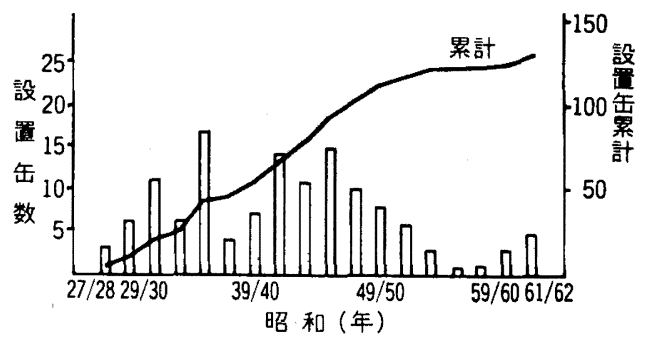

図 1 回収ボイラの設圆缶数

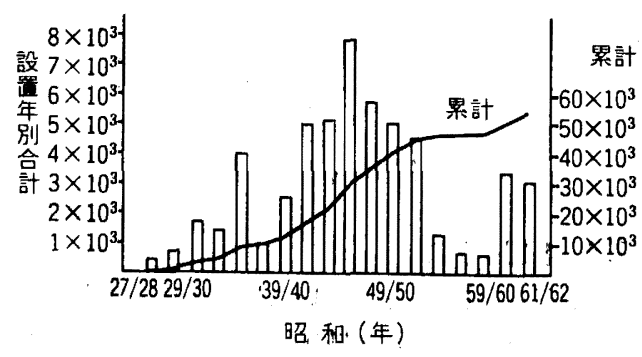

図 2 設膡缶の固形分処理量 (ton/day) 
のマクロな歴史をらかがらことが出来る。

-昭和 35〜36 年に第 1 次の完成をみた。

・昭和 45〜46 年をピークとして第 1 次分のスクラッ プフンドビルドを含み第 2 次の完成をみたが，一巡 化およびその後の 2 度にわたる石油ショックによる 設備投資減退化で昭和 50 年代後半まで新設は見送 られた。

-昭和 50 年代後半から再び設膡缶数, 特にその黒液 固形分処理量が増加してきた。これらはすべて後に 述べる高効率回収ボイラである。

\section{2 ボイラのスケールアップ}

同様に 2 年毎の設置缶あたりの黒液固形分処理量を 图3に示す。パルブ産業の発展を衰付ける如く着実に 大形化してきた。

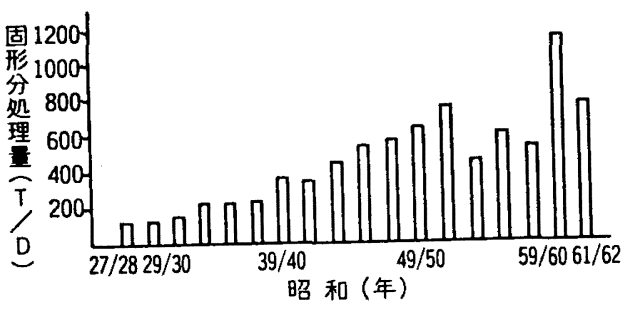

図 31 缶あたりの固形分処理量

\section{3 過熱器出口蒸気条件}

既設午を含み各 2 年毎の過熱器出口での最高蒸気条 件の変遷を図 4 に示す。最近数年間に蒸気条件が向上 したのは高奻率の要求に応えた腐食対応の技術（構造， 材料, 操業管理など）の進歩と, 省蒸気化の進んだ結 果, 負荷率が低下したり, あるい使用されなくなっ た重油ボイラ用タービン蒸気条件とのマッチングよよ るものである。

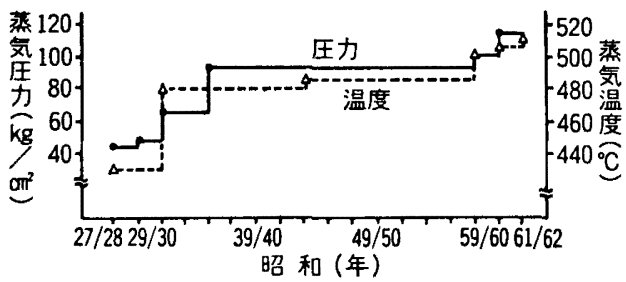

图 4 蒸気条件の変邆

\section{4 トピックス}

以上記した通り国内において回収ボイラは 30 有余 年の歴史を有する。その間のトピックス事項を表 1 に 示す。
表 1 回収ボイラの変遥

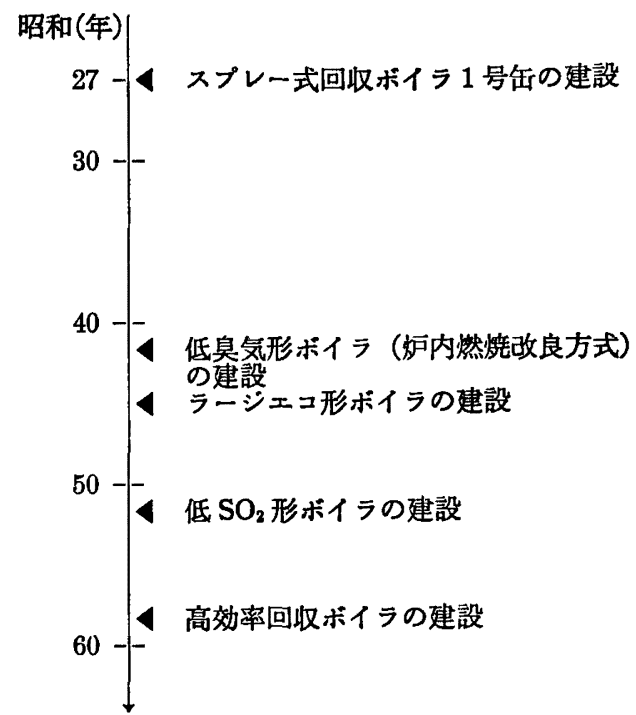

\section{5 過去の計画と通転の指針ならびに改善}

以上，データから回収ボイラの歴史を見つめたが， それとは異なり過去の歴史を計画と運転の指針ならび に改善といら面からながめてみた。

\section{1) 安定速続操業}

クローズドサイクル中の設備であるため回収ボイラ は長期の安定連続操業が必要不可欠である。腐食性の 然料でありダスティなボイラであるため，腐食・減肉 に対する配虑とダストトラブルを発生させないことと の戦いが回収ボイラの歴史であったといえる。昭和 40 年代には安定操業を確保し得るに至ったが，それは二 ーザとメーカとが一体となった努力の結実であった。 〔屒期連操面〕

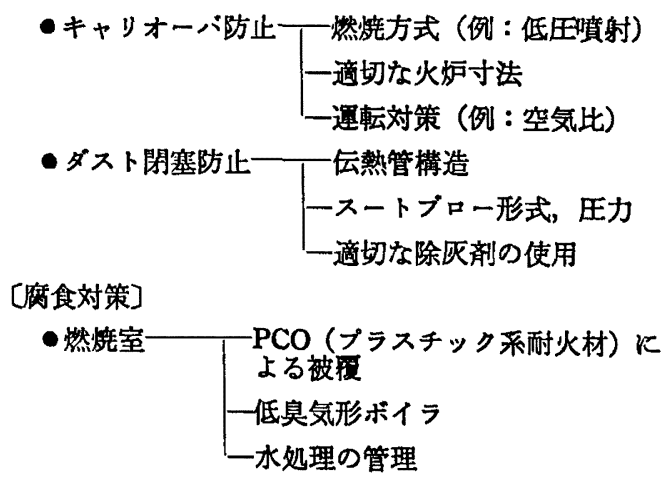

2) 少力化

回収ボイラは運転・保守共人手のかかるボイラとい われてきたが，種々な改良により省力化が図られてき た。 


\section{[運転の省力化]}

・ラージェコ形ボイラの出現

-長期連続操業の確立

・ワンタッチ黑液䅐射装置

[保守の省力化]

・停缶時のスートブロー水洗による质熱管淿除

・アルミニウムケーシンク

・補機構造の改善

3）省エネルギー

第 1 次石油ショックを契機とし一般ボイラと同様な 対策を含め，省エネルギー対策が行われてきた。

・高速トラベルスートプロー

・高効率補機（例IDF : プレート形 $\rightarrow$ エーホイル 形)

-回転数制御装置

-押込送風機効率化システム（高風圧大容量 1 台 高風圧用之低風圧用に分離）

\section{4) 低公害化}

環境基準が年々黉しくなる中で，技術確立された各 種の公害対策設備が導入されてきた。

[無臭気化]

-低臭気形ポイラ（燃焼空気投入改善）

・無臭気 (ラージェコ) 形ボイラ

・斡式ダスト処理設備

-工場全体の無臭気化一一現在では工場内で発生す る臭気ガスを回収ボイラで燃焼処理することが 一般的となっている。

[低 $\mathrm{SO}_{2}$ 化]

姖内反応の解明，シミュレーションなどにより $\mathrm{SO}_{2}$ 低下技術加確立し，それを実缺に適用（空気投入方式 の改善など）することにより $\mathrm{SO}_{2}$ 排出浇度は非常に 低下した。
[低ばいじん化〕

・高性能電気集じん機の開発

\section{3. 現在の技術}

前章に記したごとく回収ボイラは様々な改善によっ て現在では完成された設備となったが，第2次石油シ ョックを契機とし自給然料の有效活用が大きくクロ一 ズアップされ，後記する如くほとんどすべての面で二 一ザ・メーカ共同の研究・テストなどにより確認確立 された改善設借の導入によって，高効率回収ボイラが 完成した。昭和 50 年代後半以降建設されてきた回収 ボイラすべてが，以下に記す現状の最新技術の大半を 網睢した高効率回収ボイラである。その外観を写真 1

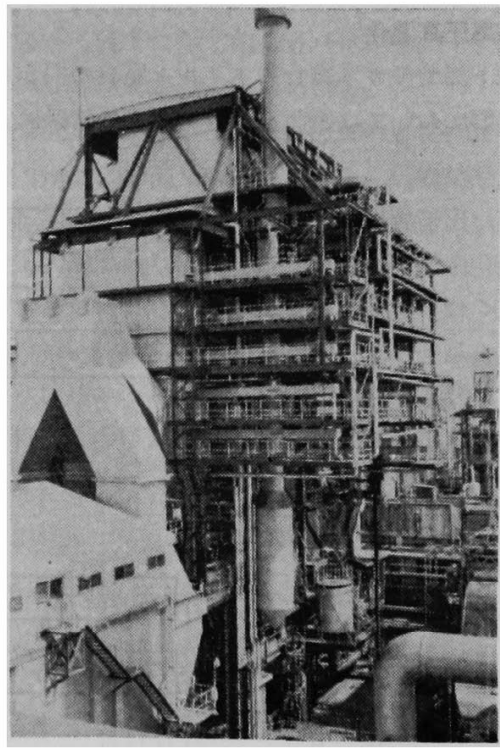

写真 1 回収ボイラの全景

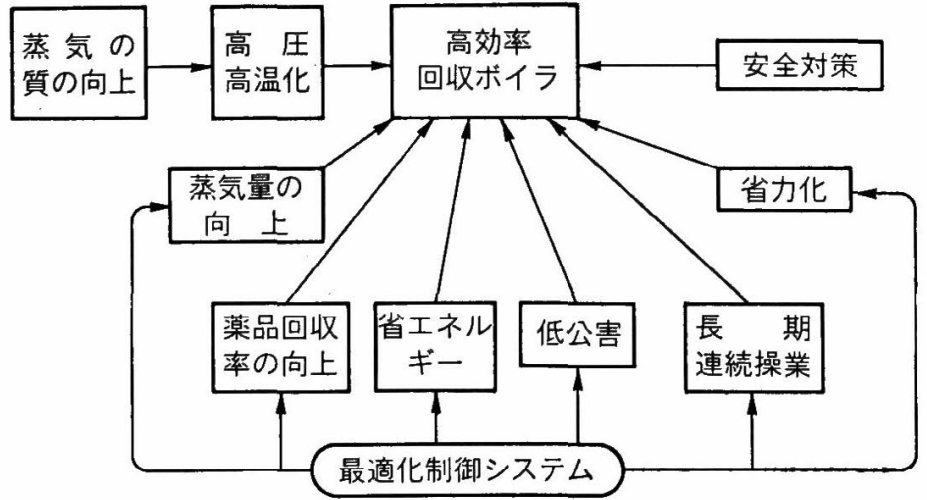

図 5 高効率回収ボイラ 
に示す。

\section{1 高効桼回収ボイラ}

高効率回収ボイラの定義はないが，筆者の考えるそ れを図5に示す。

すなわち高効率回収ボイラとは高圧高温化や蒸気量 最大化のみを指向したものではなく，従来技術でつち かわれてきた長期連続操業や安全対策にも充分配虑を 払ったものであると共に，公害対策や省エネルギーを 極限まで追求したものであり，更にコンピュータを駆 使した最適化制御システムがそれらをハッックアップし， より安定化させている設储と溇える。

なお，これを具体的な例で表わしたものが图6であ

る。以下に具体的項目の一部について内容を紹介する。

\section{2 高奻來回収ボイラの具体的な技術}

\section{1) 高王高温化}

火灯下部でのガス腐食やスメルト腐食の面から，ま た過熱器においては飛散・付着ダストの溶融による腐
食の点から，図4 亿示す通り蒸気圧力および温度は長 期間にわたり頭打ちとなっていたが，長年にわたる研 究やテストなどにより $100 \mathrm{~kg} / \mathrm{cm}^{2} \times 500^{\circ} \mathrm{C}$ 級が可能 となった。具現化し得た対策を記す。

[高圧化の対策]

・耐食鋼管の採用……ンン゚シシットチューブ（密着 二重管)，軟鋼管への肉盛りないし溶射

・ガスおよびスメルトの管への直接接触防止……ス タッド+PCO 被覆

上記対策中コンポシットチューブは，多くの回収ボ イラが設置されているスカンディナビア地域に扣いて 頻発する火炉下部管の減肉対策として,ユーザ,ボイラ メ一カおよび鋼管メーカが共同で開発した外層 SUS, 内廨㳄鋼の二重管(クラッド鋼管)で，権威あるフィン ランドの回収ボイラ委員会 (Finish Recovery Boiler Committee) が蒸気圧力の高低を問わず推奖している チューブであり，現在では全世界で 70 年以上の回収

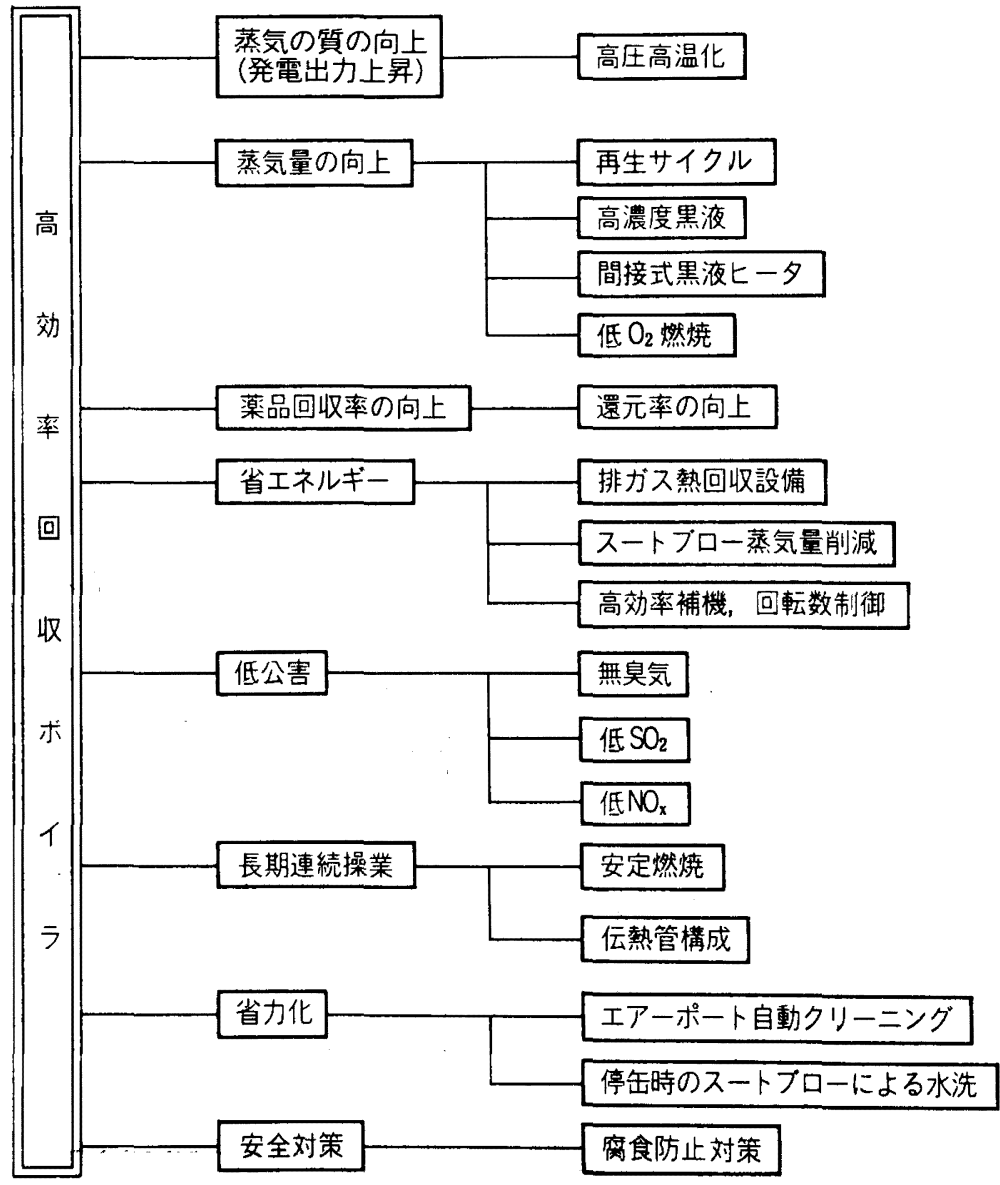

図 6 高効率回收ボイラの内容 
ボイラに採用されるなど回収ボイラの火炉下部使用管 としては最も信頼性の高いチューブであるといえる。 また火炬下部はスメルト・水爆発に対する対策として パネル構成時, 耐圧部への直接溶接のないプレフィン チューブ (一体ヒレ付鋼管) が望ましいが，その点と 腐食との雨面の対策機能を備えたプレフィンコンポシ ットチューブが世界で初めて国内の鋼管メーカにより 開発されたが，これを採用したボイラも既に稼動して いる。このプレフィンコンポジットチューブを写真 2 に示す。

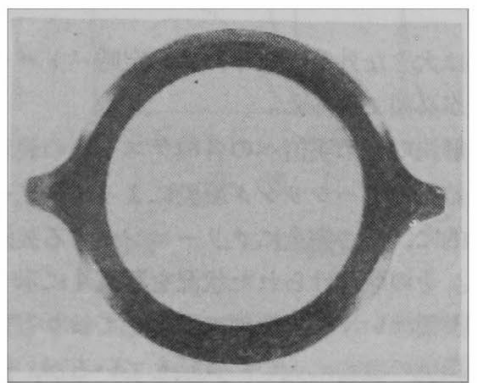

写真 2 プレフィンコンポジット チューブ

従来から採用されているスタッド＋PCO 被覆方式 も高圧化のための必要不可欠な対策であるが，これは 低負荷時や濃度低下時においても炉床を高温に保持可 能とするため低 $\mathrm{SO}_{2}$ 化や高還元率化にも大いに有効 となっている。スタッド打設中のプレフィンコンポジ ットチュープパネルの外観を写真 3 に示す。

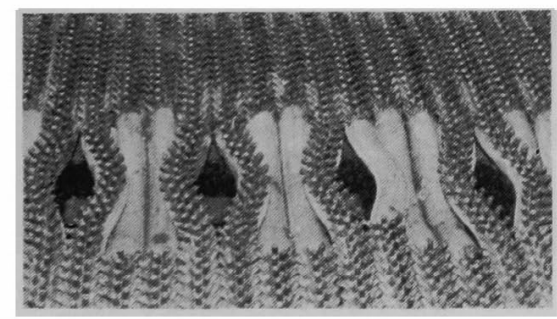

写真 3 コンポジットチュープパネル

\section{〔高温化の対策〕}

-耐食鋼管の採用

SU S347 H, YUS 170 など

- 管壁温度の低下

(1)大形ノーズヘッフル（炬内からの輻射熱シール ト)

(2)過熱器の $4 \sim 5$ 分割化

(3)パネル内でのチュープクロッシング
(4)最高温部の炬幅方向クロッシング

耐食鋼管に関してはラボテストや実缶テストによっ て確認された高級なオーステナイト系材料が使用され ており対策としては充分といえるものの，いずれも運 開後数年の実績しか無いため今後のフォローが大切で ある。

管壁温度低下対策としての 2 つのクロッシング方式 について記す。

-過熱器は長期連続操業可能となるよう炉幅方向に $400 \mathrm{~mm}$ 程度の間隔で配置された 1 ループが並列管か らなるパネル状で構成されている。火炬に面した下部 ペンド部は炉内からの輻射熱を受けその最外側管は内 側管より収熱量が多くなるため，対策を行わなければ 並列管中に蒸気温度のアンパランスが生じる。これを 防止するべく図 7 に示す如く各パネル中に 1 ケ所以上 管のクロッシングが設けられている。

一過熱器入口ガス温度は火炬水冷壁の影響により，炉 幅方向では中央が高く炉端部が低い。その結果，過熱 器での炬幅方向の収熱量が異なる。過熱器出口蒸気温 度は一定となるよう制御されているが，従来のボイラ では㭁中央部のそれは平均温度（すなわら出口検出温 度）より $20 \sim 25^{\circ} \mathrm{C}$ 高いといら測定データがある。こ のような実績から最高温部である最終過熱器は 2 分割 し，その間に設けた蒸気連絡管を図 8 に示す如く炬幅

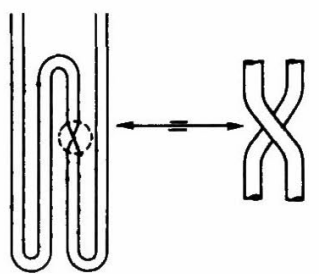

図 7 過熱管のパネル内クロッシング

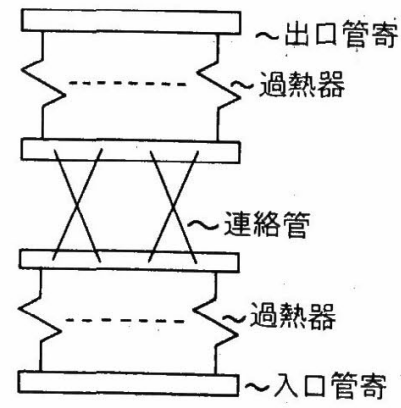

図 8 過熱管の炬幅方向クロッシング 
表 2 間接式黒液ヒータ

\begin{tabular}{|c|c|c|c|c|c|c|}
\hline 式 & 開 発 思 想 & 使 & 気 & & & 洗 \\
\hline チ=ーブ & 勢交換器としては一般 & 低 & 圧 & ナ & シ & $\begin{array}{l}\text { 予備機飞切替之, 希黒液比 } \\
\text { 乙洗淨 }\end{array}$ \\
\hline ブ & 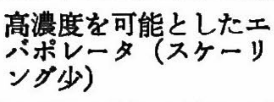 & 低 & 圧 & $ナ$ & シ & $\begin{array}{l}\text { 予備機に切替之, 希黒液に } \\
\text { て洗浄 }\end{array}$ \\
\hline ロ-タy- & $\begin{array}{l}\text { 発生したズケてルを常 } \\
\text { 時はく離させる }\end{array}$ & 中 & 圧 & & & 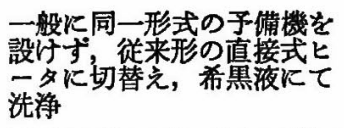 \\
\hline
\end{tabular}

方向にクロッシンクして管壁温度の低下を図っている。

耐食鋼管採用の他このようなきめ細かい配虑によっ て高温化が実現した。

2）黑做湟度低下防止一一間接式黑液ヒータ

プレート形漫紑装盾の出現により黑液の高莀度化が 容易となり，70\%ないしそれを上䢙る濃度で供給され ていることが回収ボイラ高効率化の一つの大きな要因 となっている。黒液は良好な噴茅を継続させるため粘 度低下・調整が必要であるが，その手段として從来は 中圧系蒸気を黒液に直接吹込んでいたが，それでは仕 上り黒液の濃度を低下させるためボイラ効率の低下を 招くと共に, 機器・計器トラブルの場合にはスメル ト・本爆発をひき起しかね焳慮もあった。この対策 として蒸気との熱交換による間接式黒液七一タが実液 によるテストを重权開発された。現在，国内に批いて は 3 種類の間接式ヒータが採用されているが，その特 徵などを表 2 にとめた。

なお，間接式黑液ヒータのメリットは上記の他，後 述する最適化制御システム中のドロッブサイズ制御 （チャーペッドレベル制御）の噴射黒液温度コントロ ールの外乱を除去しているため，その制御の安定性に 寄与している点にもある。直接吹込ヒータの埸合でも 黑液温度コントロールは可能だが併せて黑液濃度も変 化すなかり外乱要因となり，制御系の安定を乱して いるからである。

\section{3） エアーポート自䵢クリーニング装是}

人手の加るボイラといら回収ボイラのイメージは 火炬下部の然焼空気投入口（エアーポート）に付着す るスメルト，ダストの除去のため数時間每にペトロー ルしなければならなかったからであったといっても過 官ではない。付着により風圧が変化しエフーポート各 段風量が変化する他，同一段中でもエアーポート毎に 付着状態が巽なり, その結果, 各エフーポート風量に アンパランスが生じるため特に付着スピードの早い最 下段の 1 次エアーポートの場合チャーベッド形状の安
定化には大きな外乱となるため，定時パトロールによ る掃除が必要であった。

この解決のため実缺への各種テスト機の装着・作動 確認の結果エアーシリンダ駆動によってエフーポート を自動的に，かつ完全にクリーニングする装置が開発 された。その取付けられた状況を写真 4 亿示す。設置 された設備はいずれる順調傢動しており省力化およ び労働磦境の改善に大いに貢嗝しているが, 前述した 通り, チャーペッド形状安定化の外乱を除去している ため, 本装監も最適化制御システム中のチャーベッド レベル制御を行う前提設備となっていることも見逃せ ない効果である。

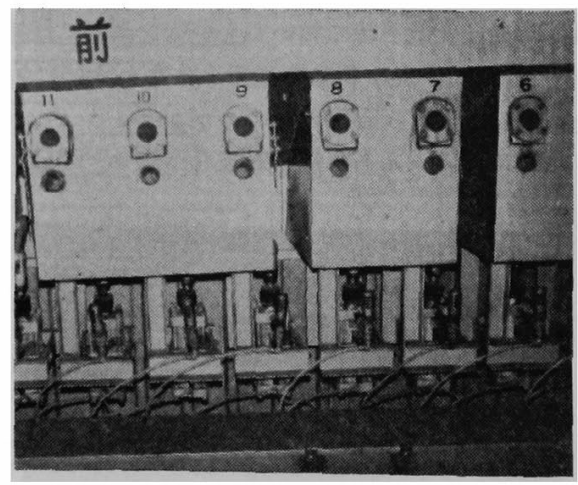

军真 4 エアーポート自動クリーニング装置

\section{4） 低 $\mathrm{SO}_{2}$ ，高㞇元率}

回収ボイラの $\mathrm{SO}_{2}$ 排出濃度を低減させる理論は炬 内反応の解明などにより既に確立されている。すなわ ら「発生する $\mathrm{SO}_{2}$ ガスを $\mathrm{Na}$ Vapour と反応させる ことにより脱硫させる。従って発生 $\mathrm{SO}_{2}$ 以上の $\mathrm{Na}$ Vapour を発生させれば理論的には $\mathrm{SO}_{2}$ はぜ口とな る。この Na Vapour の発生は炬床をある温度 (1400 `K) 以上とすること」である。従って炉林を常に高温 に保持し得る設備・運転により, 排出 $\mathrm{SO}_{2}$ 濃度を常 そ数 ppm に保持することが可能である。 


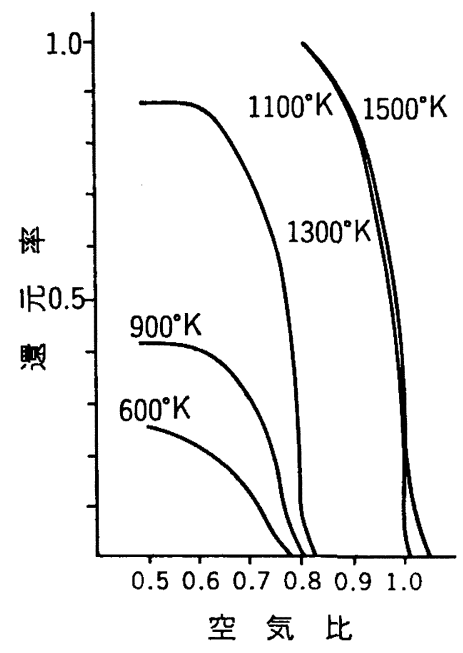

図 9 スメルト還元率

一方スルト還元率については，その理論は古くか ら確立されている。図 9 性理論式に基つく計算結果で あるが，1次空気比を押えた中で如床温度を高めるこ とにより常に高還元率を得ることが可能である。

すなわち, $\mathrm{SO}_{2}$ minmum 化とスメルト還元率 maximum 化とは相反するものではなく同一の対策一妒 床を高温に保持する—ことにより達成し得る。この 具体的な設備・運転対策としては下記のすべてが満足 されている必要がある。

\section{・高浱度黑夜然焼}

・適正なチャーベッド形状ならびにレベル

・チャーベッド直上部への大量空気投入

・䢬流芒硝の均一化

これによって常時 $\mathrm{SO}_{2}$ は0〜数 $\mathrm{ppm}$, スメルト還 元率は 95〜96\% 以上飞保つことが出来る。

上記対策中チャーペッド直上部への大量空気投入と はそれによる然烧輻射熱をチャーベッドに与えるるの であり，そのため高効率ボイラでは従来形ボイラに比 して，一般に 2 次空気レベルは低くなり，かつェアー ボート断面頽は大さくなっている。

浐流芒硝の均一化……節炭器ホッパや電気集しん機 で捕集され黒液に浐流されるタ゚スト（大半芒硝）は， 黒液の見掛け浱度を上界させるものの無機物であるの で発熱量を低下させ，炬床の高温度保持を阻害する。 常時一定量が回收される場合飞は影響は何ら表われな いが，スートプロー直後とそれ以外では捕集ダスト量 には数倍の差があり, 常時一定ではなく,スートブロ 一直後のダストを回収すると発熱量が大幅低下し炉 床温度を低下させる。このダスト量均一化には，芒硝
ミキサの容量アップ，一般に大きな容量を持つ濃黑液 タンクへの回収，乾式による均一フィード方式などが 考えられるが，実用化され大きな効果を発揮している ものとしては濃黒液タンクへの回収方式であるといえ よう。

なお，このような低 $\mathrm{SO}_{2}$ ，高罯元率を指向すると理 論から明らかなよらに飛散ダスト量が増加するので云 熱管ピッチなどの構成が完全でなければ云熱管閉塞の 照念が生じる。実際, 高濃度化後数缶に括いて過熱器 などのハンドランシングが必要となっていることは, 他の要因もあろうが高濃度化，低 $\mathrm{SO}_{2}$ 化もダスト飛 散・付着状況を把握しつつ行らべきことを示唆してい ると考学る。

\section{5）スートブローによる水洗}

停缶時のスートプローによる水洗システムは比較的 屒い歴史を有しているが，採用されているボイラは少 ないので“最近の技衍”の一つとして紹介する。

定期検査などによる長期停缶時, 回収ボイラ各部公 熱面のダスト㛿除はその後の連続操業のために，また 伝熱管のチェックのためにも必要不可欠な作業である が, 従来の手作業の場合, 固形分処理量 $600 \sim 700 \mathrm{~T} / \mathrm{D}$ クラスで通常 3 日程度必要であった。これをスートブ ローによる水洗にて行らと，8〜10 時間で手作業以上 の清浄さに掎除可能である。（但し若干の設備增強が 必要）これにより定修費用が少なくなると共にその期

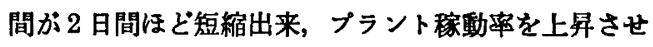
ることが出来る。

なお，現在この水洗が行われているのはバンク以降 の対流云熱面であり, 過熱器部の掃除は従来通りの手 作業である。その大きな理由は水洗水が火火炬下部の PCO と管表面の間に侵入することによる腐食を愻念 したことであるが，前述のコンポジット採用缶にはそ れる小さいと考学られるので，何らかの方法による確 認忙必要とするものの過熱器のスートブロー水洗に可 能な道も開かれたといえる。

6）最道化制御システム

ハード設備の改善, 運転保守技術の進歩などにより 回収禾イラは飛墔的に安定化・高効率化されたが，コ ンピュータを使用することにより一層の安定化・高効 率化を四ったものが最適化制御（コンビュータコント ロール) システムである。最適化制御システムは一般 に表 3 に示す5つの制御機能ブロックより構成されて いる。

システムの詳細は数多く発表されている各誌を御臨 いたたくこととし，最近のトピックスなどを紹介する。 国内において採用されている垠適化制御システムと 


\begin{tabular}{lll} 
松男 \\
\hline
\end{tabular}

表 3 最適化制御システム

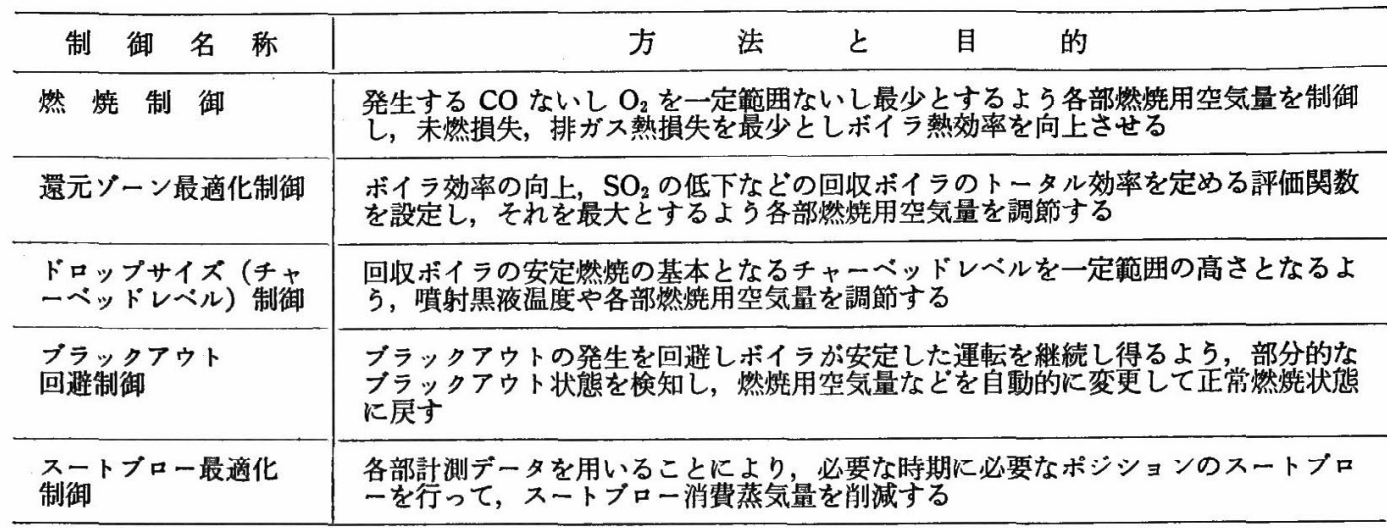

表 4 両方式の主たる相違点

\begin{tabular}{|c|c|c|}
\hline$\cdot \quad \cdot$ & 海 外 某 社 方式 & 国内 3 社 方 式 \\
\hline 動作の透明感 & 詳細動作表示画面少 & 詳細動作情報表示多 \\
\hline メンテナンス性 & メンテナンス画面少 & メンテナンス画面豊富 \\
\hline 操業要請による変更 & $\begin{array}{l}\text { メーカチューニング要員によるチューニ } \\
\text { ソグあるいはプログラ変更要 }\end{array}$ & 操業側にて可変 \\
\hline 外乱補償機能 & 多くは探索機能にて対応 & $\begin{array}{l}\text { 外乱特性, ボイラ特性を考虑した各種補 } \\
\text { 䁲機能あり }\end{array}$ \\
\hline
\end{tabular}

しては, 海外の某計装メーカ方式と, 国内の 3 社（紙 パルプメーカ・計装メーカ・ボイラメーカ) 共同開発 方式とがある。機能的には基本は同一であるが詳細な 面では相逢点が多い。その主要な相違点を表 4 に示す。 国内 3 社方式のものは各社が夫々專門分野の/ウハウ 一一紙パルプメーカは操業管理技術, 計装メーカは制 御・コンピュータ技術, ボイラメーカは設計・制御技 術一一提供をべースとし開発されたものである。

いずれの方式も低 $\mathrm{O}_{2}$ 運転, スートブロ一蒸気削减 などにより 1 缶あたり年間数千万円の運枟メリットの ほか定量的算出は難しいが，ポイラの超安定化などの 大きなメリットもあったといわれている。

本最適化制御システムとハード設備との関係につい て記す。それは最適化制御の効果を発挥させるために は，ハード設倩か図 5 や図6に示す高効率設借となっ ていることが理想的であるといら点である。その理由 としては前述の如くェアーポートの自動クリーニング 装置はチャーペッドレペル制御の外乱を除去している し, 間接式 BL ヒータは制御系の安定に大いに寄与し ている。更に効果として取上げられる低 $\mathrm{O}_{2}$ 運転は八 一ド側での種々な改善がベースとしてあり，また伝熱 管構成が不適切であればダストトラブルが発生し易く,
スートブロー最適化制御の効果も充分発揮出来ないと 考えられるからである。

なお，本最適化制御システムとも関連し，回収ボイ ラにおいて制御盤を排した完全ボードレス化（公害監 視計器のみの盤を有する) の制御システムも出現して いる。その制御室内の状況を写真 5に示す。

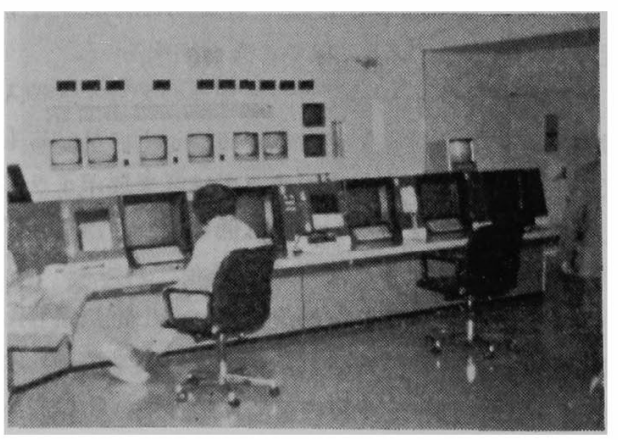

写真 5 ボート゚レス制御室

\section{4. 将来の展望}

技術の進歩により回収ボイラは，今や重油や石炭を 然料とするボイラと比べても劣らぬはど高効率化され 
た設備となったといえる。しかしながら，更に安定化 したより高効率の設備とするよら追求しなければなら ぬことは論を待たない。将来予測されるニーズ，今後 の動向の一端を“将来の展望”として私見を記す。

\section{1 蒸気条件の向上}

一つの節目である $100 \mathrm{~kg} / \mathrm{cm}^{2} \times 500^{\circ} \mathrm{C}$ といら蒸気 条件は実現した。しかしこの蒸気条件は，蒸気原動所 として圧力・温度バランスの面からみると多少イレギ ニラーであり，殴力 $100 \mathrm{~kg} / \mathrm{cm}^{2}$ とすると温度は 520 〜540 C とするのが一般的である。 $\left(100 \mathrm{~kg} / \mathrm{cm}^{2} \times 500\right.$ ${ }^{\circ} \mathrm{C}$ は压力に対し温度が低いため，ターピンでの仕事 の結果プロセス用として使用されるタービン背気温度 が飽和に近ついたり，復水の場合には最終段において ドレンカットが生じ易くなる)

この解決のためには 2 つの検討ポイントがある。一 つは当然ながら過熱管の耐食性であり，各所で腐食テ ストが更に継続して行われるなど，より高温化に向け て研究中である。今一つは回収ボイラの熱バランス面 からの検討である。火妒での完全然焼，キャリオーバ 防止などの点から他然料ボイラに比し火炬容積が大き いため, 過熱器入口ガス温度は最高でも $950^{\circ} \mathrm{C}$ と低い。 蒸気温度を高めればガス・蒸気温度差が小さくなるの で過熱器の层熱面積が増加するため大幅にコストアッ プし，結果，経済的に効果があるのかどうか，また技 術的にその入口ガス温度を上昇させ得た場合，回収ボ イラ重続操業面で最も重要なポイントであるパンク入 ロガス温度がハラランス上どの程度になるかなど検討事 項は多い。

また，一方それと共に圧力の上昇化もやはり検討対 象事項であるが，近い将来に限れば $100 \mathrm{~kg} / \mathrm{cm}^{2}$ 級 での実績，耐食鋼管の信頼性のフォローを裙実に行っ ていくことが商切な手法であろら。

\section{2 高湿度化}

70〜 72\% 程度の高濃度黒液の安定した供給が回収ボ イラの高効率化を具現化させた大きな一つの要因であ ることを記したが，それでもな怙回収ボイラの熱効率 が高位発熱量べースで70\%を若干上佪る程度に留ま っているのは，黑液中の水分がいまた約 $30 \%$ 含まれ ている点が大き。従って今後今以上の高浱度化，究 極的には黒液を絶乾状態として然焼させることも期待 される。高濃度化を実現させるためには黒液の濃縮の みならず，搬送，然焼そして然䚌の結果表われる諸問 題についての研究が必要であるが，これに関しては現 在行われている直接苛性化 (DARS) 技術の研究がプ ロセスの相違があるものの大いに参考になると考える。

\section{3 超省力化}

ハード設備に関してもまだまだ省力化などのために 改善すべき点があり，例えばロボットアームなどを使 用したスメルトスパウトや黒液ガンの自動クリーニン グ装置など対象は多い。

\section{4 操業管理のためのセンサなど}

最適化制御システムの導入と共に，パイロスコーブ など種々な操業管理用センサが開発・使用され，また 既存の濃度計からのデータなどにより黑液中の有機成 分を推定する手段が確立するなどなされているが，操 業管理を充実させるためにはいまだ不十分であり，一 部開発中のものもあるが更に下記の各種センサなどの 破立が期待されている。

・炉内然焼状態, チャーペッド形状の確認……炉内力 メラ，チャーベッド三次元形状表示

-速続測定可能な発熱量計，硫化度計， $\mathrm{NaCl}$ 沙度計， 㯰元率計，ダスト性状分析計など

\section{5 超安定化とトータル最这化}

- 超安定化……各種センサを用いて薬液状態，然料性 状，燃烧状態を常時正確に把握してあいまいさを減ら すと共に，信号処理技術の進歩とあいまって超安定化 を図る。

・マスター制御……後一周の省蒸気化によって自給 燃料である回収ボイラのみの蒸気原動所が增加すると 考えられ，従って回収ボイラでのマスター制御（黑液 流量制御）が必要となろら。このためには，現在それ を阻害しているチャーベッドのコントロールが最適化 制御システムの導入で道づけされたので，これを土台 として開発していくことになろら。

・ミルワイドシステム……ローズドサイクル，工場 トータルといら視点から他工程，プラント鋽成を考感 しての安定化，高効率化を図る。

\section{5. あとがき}

回収ボイラの足跡をふり返ると共に現状の技術を紹 介し，更に将来の展望について記した。一部でも読者 諸氏の御参考になれば幸いである。将来の薿望に関し ては私見であるため，既に陳腐な項目がある場合など 御了解願いたいと共に，今後それに関し多くの場で関 係者が議論するのは多いに央のあることだと思ら。な 版末尾ではあるが本稿作成にあたり，十條製紙株式会 社釧路工場ならびに八代工場の御担当各位に贵重な御 意見をいただき，その一部を使用させていたたいたこ とに紏面を借り厚く扮礼申し上げます。 